\title{
Synthesis, Characterization, and Study of Proton Exchange Polymer Membrane Properties of Sulfonated Copolymer Eugenol-diallyl Phthalate
}

\author{
Ngadiwiyana $^{1, *}$, Nor Basid Adiwibawa Prasetya ${ }^{1}$, Gunawan $^{1}$, Tutuk Djoko Kusworo ${ }^{2}$, and Heru Susanto ${ }^{2}$ \\ ${ }^{1}$ Department of Chemistry, Faculty of Science and Mathematics, Universitas Diponegoro, \\ Jl. Prof. Soedharto SH, Tembalang, Semarang 50275, Indonesia \\ ${ }^{2}$ Department of Chemical Engineering, Faculty of Engineering, Universitas Diponegoro, \\ Jl. Prof. Soedharto SH, Tembalang, Semarang 50275, Indonesia
}

*Corresponding author:

tel: $+62-82135243883$

email: ngadiwiyana@live.undip.ac.id

Received: March 17, 2020

Accepted: August 31, 2020

DOI: $10.22146 /$ ijc.55353

\begin{abstract}
Synthesis biopolymer of sulfonated copolymer eugenol-diallyl phthalate (PEGDAF), its characterization, and study of proton exchange polymer membrane properties had been done. This synthesis was conducted by eugenol and diallyl phthalate reaction to form PEGDAF, which is sulfonated using sulfuric acid. In addition, the functional groups of the PEGDAF and its sulfonated form were analyzed using FT-IR. Furthermore, the polymer properties were determined by measuring values of sulfonation degree, cation exchange capacity, proton conductivity, and water uptake. FT-IR spectra showed that the vinyl group had been added to the process of PEGDAF formation, while spectra deconvolution was used to confirm the occurrence of sulfonation reaction. The sulfonation of PEGDAF in $2 \mathrm{~h}$ optimum reaction time produces a black solid with a melting point of $133^{\circ} \mathrm{C}$ in $16.55 \%$ yield. The highest proton conductivity, cation exchange capacity (CEC), and water uptake were $8.334 \times 10^{-6} \mathrm{~S} \mathrm{~cm}^{-1}, 0.44 \mathrm{meq} / \mathrm{g}$, and $73.0 \%$, respectively.
\end{abstract}

Keywords: eugenol; diallyl phthalate; membrane; proton exchange; polymer

\section{INTRODUCTION}

In recent years, the development of polymer materials from renewable bioresources has become an interesting study due to the decrease in fossil oil resources and increased environmental problems such as $\mathrm{CO}_{2}$ emission and the greenhouse effect [1]. A study conducted in the United States of America predicts 90\% of organic chemical products from renewable natural resources in 2090 [2]. Therefore, it is important to determine and propose renewable natural resources as an alternative to fossil oil, especially for polymer industries [1].

One of the renewable natural resources used for polymer synthesis is eugenol, which acts as the major constituent of clove oil (Eugenia caryophyllata), with 70$90 \%$ contents [3]. Eugenol has several functional groups of allyl, methoxy, and hydroxy, so it can be transformed into other useful compounds [4]. Moreover, the presence of an allyl group $\left(-\mathrm{CH}_{2} \mathrm{CH}=\mathrm{CH}_{2}\right)$ enables the occurrence of polymerization through an addition reaction. Several studies have been carried out on the synthesis of polymers from eugenol and the products were used as antibacterial and antioxidant agents, as well as biorenewable thermosetting materials [4-5].

Eugenol based polymers have structures that are similar to polystyrene with the aromatic rings in the phenolic $(-\mathrm{OH})$ groups used to release protons, therefore they have the potential to be used as polymer membrane fuel cells. This is in line with the advanced research on non-fluorinated polymers for fuel cell membranes such as sulfonated polystyrenes (PS), polyimides, poly(arylene ether ketone) [6], high-impact polystyrene (HIPS), HIPS doped with poly (styreneethylene-butylene) (SEBS) [7], and styrofoam waste [8].

The eugenol polymer structure could be modified to improve its ability as a polymer membrane fuel cell. Cross-linked on Eugenol polymer could limit the swelling degree values [9] and diallyl phthalate could be used as a linker [10]. In this case, two allyl groups on diallyl phthalate will bind to the allyl group from eugenol

Ngadiwiyana et al. 
to form a crosslinked polymer. This copolymerization process could be performed via cationic polymerization using a Lewis acid catalyst, $\mathrm{BF}_{3} \mathrm{O}\left(\mathrm{C}_{2} \mathrm{H}_{5}\right)_{2}$ [11].

Eugenol-diallyl phthalate copolymer (PEGDAF) is expected to have a low swelling degree, making it possible to be a stable polymer for the polymer electrolyte membrane [12]. Therefore, the modification of PEGDAF could be conducted with the addition of sulfonate groups using sulfuric acid as a sulfonation agent [13]. Sulfonate group is defined as a superacid functional group which easily transfer protons [14], thus opening up the opportunities for PEGDAF to be used as a basic ingredient for polymer electrolyte membrane (PEM). In addition, the ideal electrolytic polymer membrane needs to have a large proton conductivity and cation-exchange capacity to assure high current density [15-16]. Moreover, water uptake also plays an essential role in proton conduction through the dissociation of sulfonic acid groups and the facilitation of transported protons [17]. Therefore, this research aims to synthesize PEGDAF and sulfonate PEGDAF using time variation, characterize the sulfonated PEG-DAF, and determine the PEM properties such as the degree of sulfonation, proton conductivity, cation exchange capacity, and water uptake.

\section{- EXPERIMENTAL SECTION}

\section{Materials}

The materials used were eugenol, boron trifluoride etherate, methanol, diethyl ether, chloroform, sodium sulfate anhydrous, sodium hydroxide, and sodium chloride obtained from Merck. In addition, the diallyl phthalate and sulfuric acid (98\%) were obtained from Sigma Aldrich and Mallinckrodt, respectively.

\section{Instrumentation}

The instruments used were a set of reflux apparatus, an oven, FTIR (Perkin Elmer Spotlight 200S/N9676696681), porcelain cups, Ubbelohde viscometer, and LCR Meter (HOKI 3522-50 LCR HITESTER). The thermal analysis was carried out under a nitrogen atmosphere using Thermogravimetric Analyzer (TG7300) at a temperature range of $50-700{ }^{\circ} \mathrm{C}$ with a $5{ }^{\circ} \mathrm{C}$ heating rate per minute and platinum as the reference material.

\section{Procedure}

\section{Copolymerization of eugenol-diallyl phthalate (PEGDAF)}

Eugenol $(65 \mathrm{mmol})$, diallyl phthalate $(6.5 \mathrm{mmol})$, and chloroform $(9 \mathrm{~mL})$ were added into a three-neck flask and stirred at room temperature under a nitrogen atmosphere. This was followed by a dropwise addition of boron trifluoride etherate catalyst $(1 \mathrm{~mL})$ then the reaction allowed to curdle and the copolymerization stopped by adding $2 \mathrm{~mL}$ of methanol. The copolymerization product was dissolved in diethyl ether and washed with distilled water to obtain a neutral $\mathrm{pH}$. The organic phase was added with anhydrous $\mathrm{Na}_{2} \mathrm{SO}_{4}$ to absorb the remaining distilled water, the solvent was evaporated in a water bath at $50^{\circ} \mathrm{C}$ and finally, the residue was stored in a desiccator. The copolymerization product (PEGDAF) was analyzed for its functional groups using the FTIR spectrophotometer [18] and the physical properties were performed by measuring its melting point, solubility, and swelling degree, while the molecular weight was determined using the viscometry method.

\section{Sulfonation of PEGDAF with $\mathrm{H}_{2} \mathrm{SO}_{4}$}

PEGDAF ( $4 \mathrm{~g}$ ) was added to $60 \mathrm{~mL}$ of chloroform in the beaker and stirred until homogeneous. The PEGDAF solution was then put into a three-neck flask and refluxed at $60^{\circ} \mathrm{C}$ with the addition of concentrated sulfuric acid (1.6 mL, $0.03 \mathrm{~mol})$ and stirred. The sulfonation reactions were carried out during time variations of $1.5,2.0$, and $2.5 \mathrm{~h}$. Each solution was added with cold distilled water to form two layers and separated using a separating funnel. The organic layers were washed with distilled water to a neutral $\mathrm{pH}$, evaporated until dry, and kept in a desiccator. The various sulfonated PEGDAF obtained was then analyzed to determine its functional groups using an FTIR spectrophotometer [19].

\section{Determination of the degree of sulfonation (DS) of sulfonated PEGDAF}

The degree of sulfonation (DS) was determined using the acid-base titration method. This was carried out by immersing sulfonated PEGDAF $(0.1 \mathrm{~g})$ into $10 \mathrm{~mL}$ of $\mathrm{NaCl} 0.1 \mathrm{M}$ solution for $48 \mathrm{~h}$. After separation, the filtrate was obtained and titrated with $\mathrm{NaOH}(0.02 \mathrm{M})$

Ngadiwiyana et al. 
using PP indicator [20]. The degree of sulfonation is obtained from Eq. (1) [20].

$$
\mathrm{DS}=\frac{\text { Volume }_{\mathrm{NaOH}} \times \text { Molecular weight }_{\text {monomer }}}{\text { sample weight }}
$$

\section{Determination of cation exchange capacity (CEC)}

The sulfonated PEGDAF $(0.1 \mathrm{~g})$ was immersed in 10 $\mathrm{mL}$ of $\mathrm{NaCl} 0.1 \mathrm{M}$ solution for $48 \mathrm{~h}$. Furthermore, it was filtered to obtain residues and filtrates, which were titrated with $0.02 \mathrm{M}$ of $\mathrm{NaOH}$ using phenolphthalein (PP) indicator. The CEC values can be obtained from Eq. (2).

$\mathrm{CEC}=\frac{\text { Volume }_{\mathrm{NaOH}} \times \text { Concentration }_{\mathrm{NaOH}}}{\text { sample weight }}$

\section{Determination of proton conductivity}

The sulfonated PEGDAF was prepared into a pellet with a thickness and diameter of 5 and $10 \mathrm{~mm}$, respectively, using a 300 psi pressurized Enerpac machine. The frequency used in this study was $1-100 \mathrm{kHz}$ with a voltage of $20 \mathrm{mV}$. Subsequently, the sulfonated PEGDAF was clamped between 2 electrodes connected to the positive and negative poles of the LCR meter to measure its impedance. Proton conductivity can be calculated using Eq. (3).

$\rho=\frac{\mathrm{R} \times \mathrm{A}}{\mathrm{i}} ; \sigma=\frac{1}{\rho}$

\section{Determination of water uptake}

Water uptake was determined by the ratio of dry and wet masses of each polymer sample. The sulfonated PEGDAF was dried in an oven at $60{ }^{\circ} \mathrm{C}$ for $3 \mathrm{~h}$ and weighed to obtain a dry weight $\left(\mathrm{W}_{\mathrm{dry}}\right)$. Furthermore, the sulfonated PEGDAF was immersed in $2 \mathrm{~mL}$ of distilled water for $24 \mathrm{~h}$ with the residue separated and drained to obtain the wet weight $\left(\mathrm{W}_{\text {wet }}\right)$. The water uptake value is obtained from Eq. (4) [20].

$\mathrm{WU}(\%)=\frac{\mathrm{W}_{\text {wet }}-\mathrm{W}_{\text {dry }}}{\mathrm{W}_{\text {dry }}} \times 100 \%$

\section{- RESULTS AND DISCUSSION}

\section{Copolymerization of Eugenol-diallyl Phthalate (PEGDAF)}

The copolymerization of eugenol and diallyl phthalate was carried out based on the method conducted by Kiswandono et al. [18] and modified using the crosslinking agent. In this research, diallyl phthalate acts as a cross-linking agent in the copolymerization of eugenol, which takes place through the cationic addition polymerization reaction. This reaction is conducted in three stages, namely initiation, propagation, and termination. The initiation stage is marked by a change in color from clear to blackish brown and this is followed by the propagation stage that takes place during the stirring process. At the termination stage, copolymerization is quenched by the addition of methanol, with the reaction characterized by the formation of a purple gel. The final product is a brown solid with a melting point of $84^{\circ} \mathrm{C}$, a molecular weight of 6329.913 Dalton, and a yield of $85.96 \%$.

The FTIR spectra of PEGDAF compared to eugenol, which acts as the monomer, is shown in Fig. 1. Eugenol has absorption at a wavenumber of $1637 \mathrm{~cm}^{-1}$, which is responsible for $\mathrm{C}=\mathrm{C}$ alkene of the allyl group. Meanwhile, the spectrum of PEDGAF does not show this wavenumber, indicating that the copolymer product has been formed with the loss of the vinyl group. In addition, the wavenumber of the PEDGAF spectrum at the peaks of 1724 and $1271 \mathrm{~cm}^{-1}$ are responsible for $\mathrm{C}=\mathrm{O}$ and $\mathrm{C}-\mathrm{O}$ ester groups of diallyl phthalate structures, respectively. The detail of both spectra's important peaks is shown in Table 1. While comparing the spectra of eugenol and PEGDAF, there is a decrease in all peaks into lower wavenumber. This is probably due to the presence of the DAF in the copolymer which has ester groups to introduce more intramolecular hydrogen bonding through the $\mathrm{C}=\mathrm{O}$ from the ester and $\mathrm{OH}$ groups from the eugenol, thereby leading to a shift in peak value towards the lower wavenumber.

The solubility test was carried out on PEGDAF using various solvents, as shown in Table 2 . It shows that the PEGDAF completely dissolves in chloroform and diethyl ether and this result will be used for determining the appropriate solvent for the sulfonation reaction.

PEGDAF has a low swelling degree of $26.6 \%$ due to a cross-linked chain structure of PEGDAF capable of reducing the inflow of water into the polymer chain, therefore avoiding expanding. Based on this result, PEGDAF has potential as a base material for electrolyte polymer membranes. 


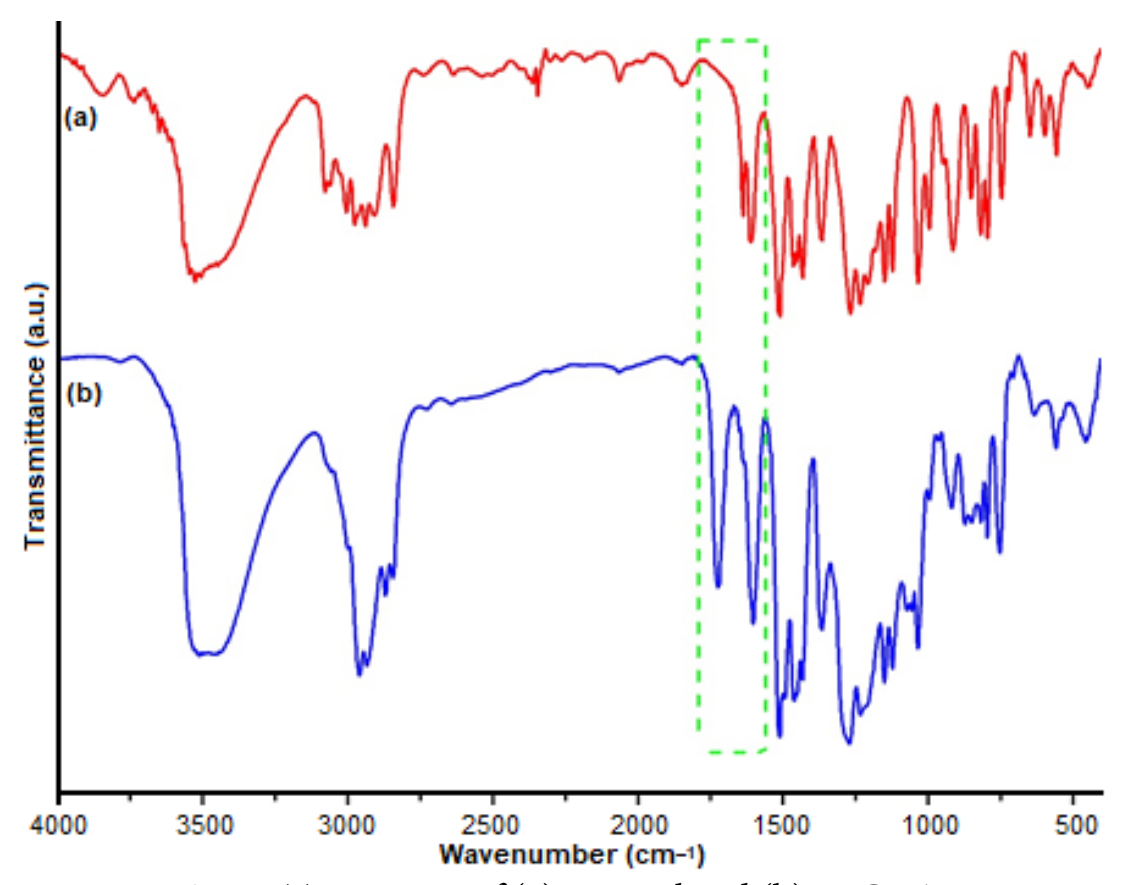

Fig 1. FTIR spectra of (a) eugenol and (b) PEGDAF

Table 1. Functional groups and wavenumbers of eugenol and PEDGAF

\begin{tabular}{|c|c|c|}
\hline \multirow{2}{*}{ Functional groups } & \multicolumn{2}{|c|}{ Wavenumber $\left(\mathrm{cm}^{-1}\right)$} \\
\hline & Eugenol & PEGDAF \\
\hline $\mathrm{OH}$ & 3525 & 3513 \\
\hline C-H sp ${ }^{3}$ (stretching) & 2976 & 2959 \\
\hline $\mathrm{C}=\mathrm{C}$ aromatic (stretching) & 1610 & 1602 \\
\hline $\mathrm{C}-\mathrm{H} \mathrm{sp}^{3}$ (bending) & 1464 & 1460 \\
\hline $\mathrm{C}-\mathrm{O}$ ether & 1233 & 1232 \\
\hline $\mathrm{C}=\mathrm{C}$ alkene & 1637 & - \\
\hline $\mathrm{C}=\mathrm{O}$ ester & - & 1724 \\
\hline $\mathrm{C}-\mathrm{O}$ ester & - & 1271 \\
\hline
\end{tabular}

Table 2. Solubility test results of PEGDAF

\begin{tabular}{lc}
\hline Solvent & PEGDAF \\
\hline Distilled water & $\mathrm{xxx}$ \\
Methanol & $\mathrm{xxx}$ \\
Ethanol & + \\
Chloroform & +++ \\
Diethyl ether & +++ \\
Ethyl acetate & ++ \\
\hline
\end{tabular}

Note: $\mathrm{x}=$ insoluble, $+=$ soluble

\section{Sulfonation of PEGDAF}

Sulfonation of PEGDAF was carried out using concentrated $\mathrm{H}_{2} \mathrm{SO}_{4}$ as the sulfonation agents (98\%) with time variations of $1.5 ; 2$; and $2.5 \mathrm{~h}$ [19]. The sulfonated PEGDAF undergoes color changes from brown to black before and after sulfonation, respectively. In addition, the sulfonation increases the melting point properties of the polymer, i.e., PEGDAF has a melting point of $84^{\circ} \mathrm{C}$, while the sulfonated state increases to $133^{\circ} \mathrm{C}$.

Sulfonation reactions mechanism with sulfuric acid is proposed in Fig. 2. The sulfur trioxide obtained from the dissociation of concentrated sulfuric acid acts as an electrophile that attracts the ring of electrons, followed by a transfer of hydrogen from the ring to the negative oxygen to obtain a sulfonated product.

It was known that both eugenol and diallyl phthalate have benzene rings as sulfonation sites. However, the benzene ring in eugenol is more activated due to the presence of electron-donating groups, such as hydroxyl, methoxy, and alkyl. Whereas diallyl phthalate has two electron-withdrawing groups, which are esters, therefore, they deactivate the benzene ring to undergo an electrophilic substitution reaction.

Analysis of sulfonated PEGDAF was carried out using an FTIR spectrophotometer to prove the occurrence of sulfonation reaction. The result of the FTIR analysis of sulfonated PEGDAF was shown in Fig. 3 and the complete absorption data before and after sulfonation was shown in Table 3. Sulfonated PEGDAF spectra show the presence of sulfonic acid group $\left(-\mathrm{SO}_{3} \mathrm{H}\right)$, which has 


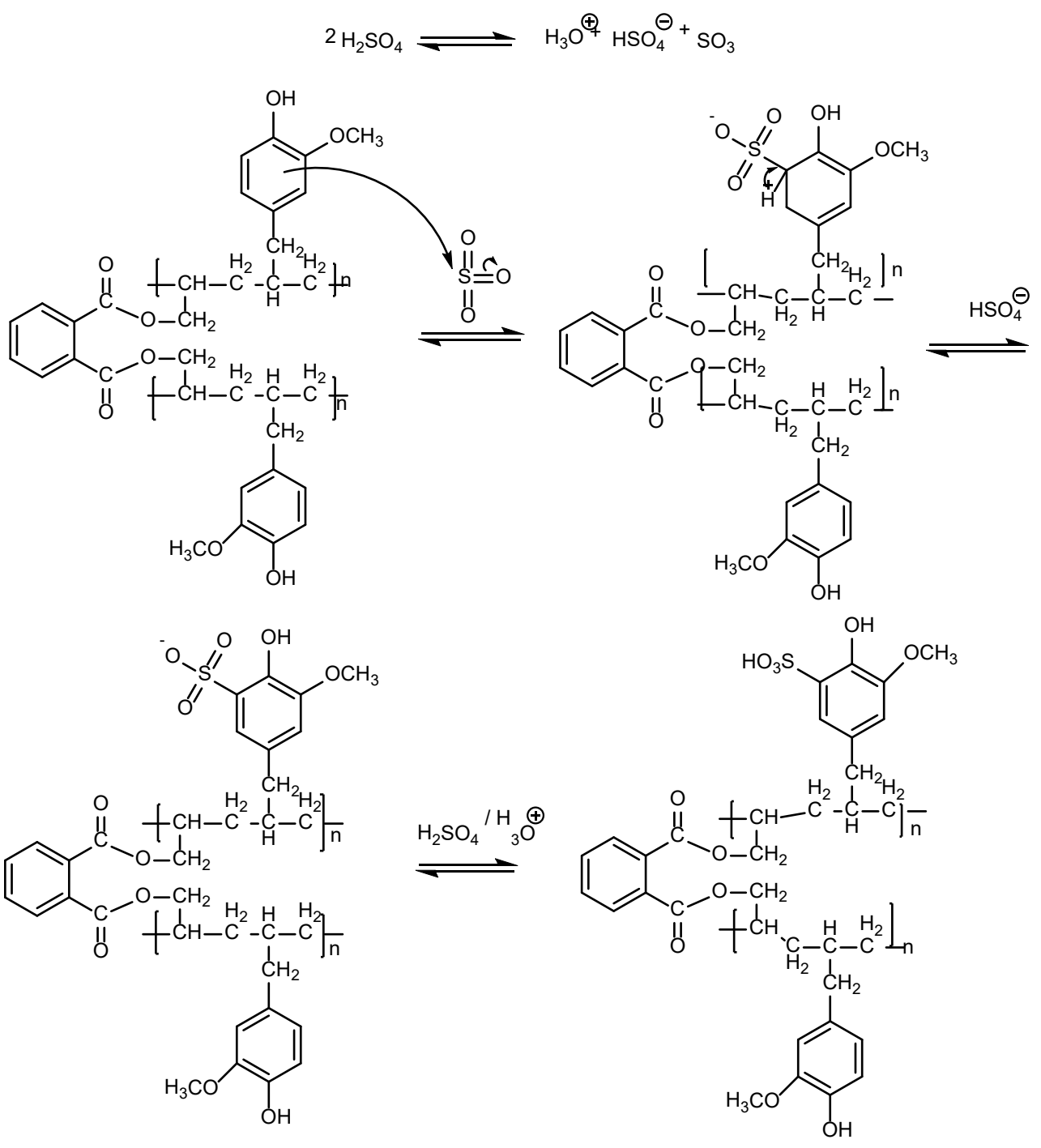

Fig 2. Mechanisms of the copolymer sulfonation reaction (PEGDAF)

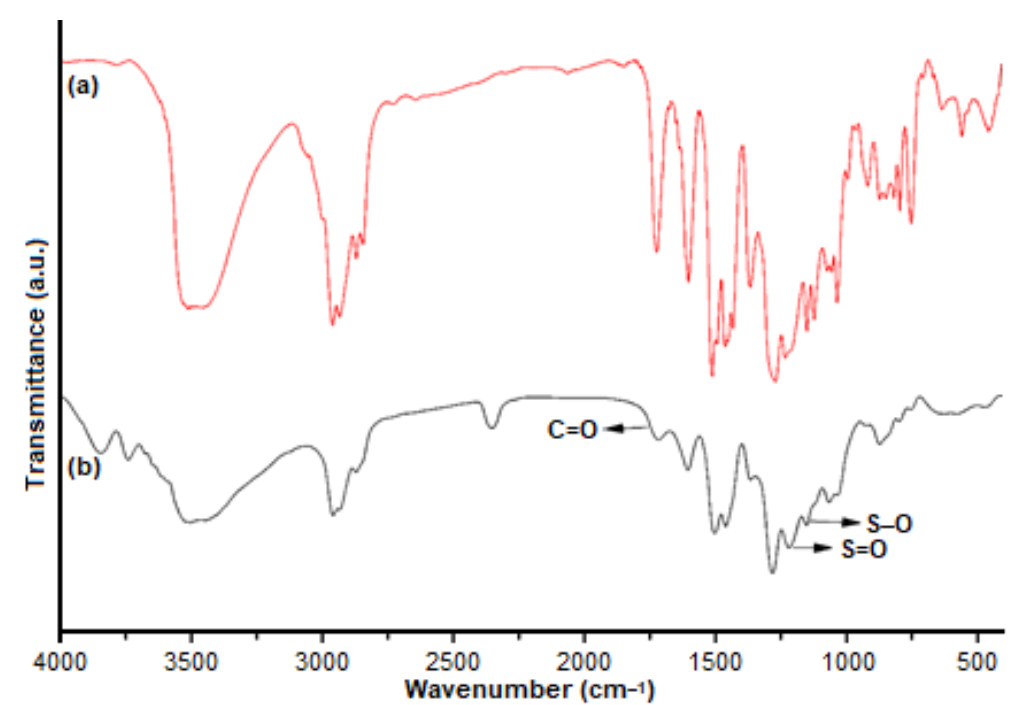

Fig 3. FTIR spectra of (a) PEGDAF, (b) sulfonated PEGDAF 
Table 3. Functional groups of PEGDAF and sulfonated PEGDAF

\begin{tabular}{lcc}
\hline Functional groups & PEGDAF $\left(\mathrm{cm}^{-1}\right)$ & Sulfonated PEGDAF $\left(\mathrm{cm}^{-1}\right)$ \\
\hline $\mathrm{O}-\mathrm{H}$ & 3513 & 3503 \\
$\mathrm{C}-\mathrm{H}$ sp & 2960 & 2958 \\
$\mathrm{C}=\mathrm{C}$ aromatic & 1603 & 1605 \\
C-O ether & 1233 & 1219 \\
$\mathrm{C}-\mathrm{H}$ aromatic (bending) & 1460 & 1459 \\
$\mathrm{C}=\mathrm{O}$ ester & 1725 & 1717 \\
$\mathrm{~S}=\mathrm{O}$ & - & 1219 \\
$\mathrm{~S}-\mathrm{O}$ & - & 1065 \\
$\mathrm{C}-\mathrm{S}$ & - & 578 \\
\hline
\end{tabular}

three absorption peaks, i.e., $1219 \mathrm{~cm}^{-1}(\mathrm{~S}=\mathrm{O}), 1065 \mathrm{~cm}^{-1}$ $(\mathrm{S}-\mathrm{O})$, and $578 \mathrm{~cm}^{-1}(\mathrm{C}-\mathrm{S})$. Thus, it proves that the sulfonated product has been yielded.

The success of the sulfonation reaction is determined by calculating the $\%$ transmittance ratio of $\mathrm{C}$ $\mathrm{O}$ ether before and after sulfonation with absorption of $\mathrm{C}=\mathrm{C}$ benzene used as an internal standard. The $\mathrm{C}=\mathrm{C}$ benzene group was chosen as a comparison because its amounts before and after sulfonation remained the same. The $\%$ transmittance ratio of $\mathrm{C}-\mathrm{O}$ ether before and after sulfonation is 0.97 and 0.88 , respectively. This difference shows that the concentration of the group in the spectra increased after sulfonation. This is in accordance with Lambert beer law, which stated that concentration is inversely proportional to transmittance. An increase in concentration after sulfonation is due to the contribution of the $\mathrm{S}=\mathrm{O}$ of the sulfonate bound to PEGDAF.

The FTIR peaks obtained for $\mathrm{C}-\mathrm{O}$ groups after sulfonation and $\mathrm{S}=\mathrm{O}$ are not clearly seen due to overlapping. Therefore, to confirm the occurrence of sulfonation, FTIR spectra deconvolution was carried out in the wavenumber area of $1180-1240 \mathrm{~cm}^{-1}$ as shown in Fig. 4. Furthermore, the deconvolution results show that when the absorption is at $1198 \mathrm{~cm}^{-1}$ (blue line), it belongs to $\mathrm{S}=\mathrm{O}$ while at $1221 \mathrm{~cm}^{-1}$ (red line) it is $\mathrm{C}-\mathrm{O}$ ether of the PEGDAF. Based on the results, it was concluded that sulfonation was successfully conducted.

\section{Determination of Sulfonation Degrees (DS)}

The degree of sulfonation was determined using the acid-base titration method [20]. The sulfonation results with time variations, which shows an increase in the degree

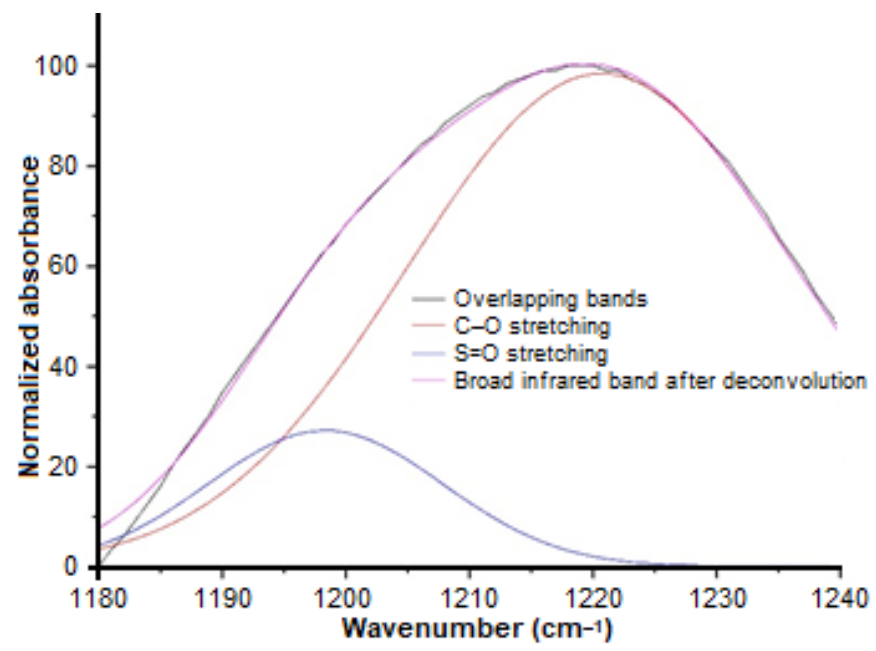

Fig 4. FTIR spectra deconvolution of sulfonated PEGDAF at absorption range of $1180-1240 \mathrm{~cm}^{-1}$

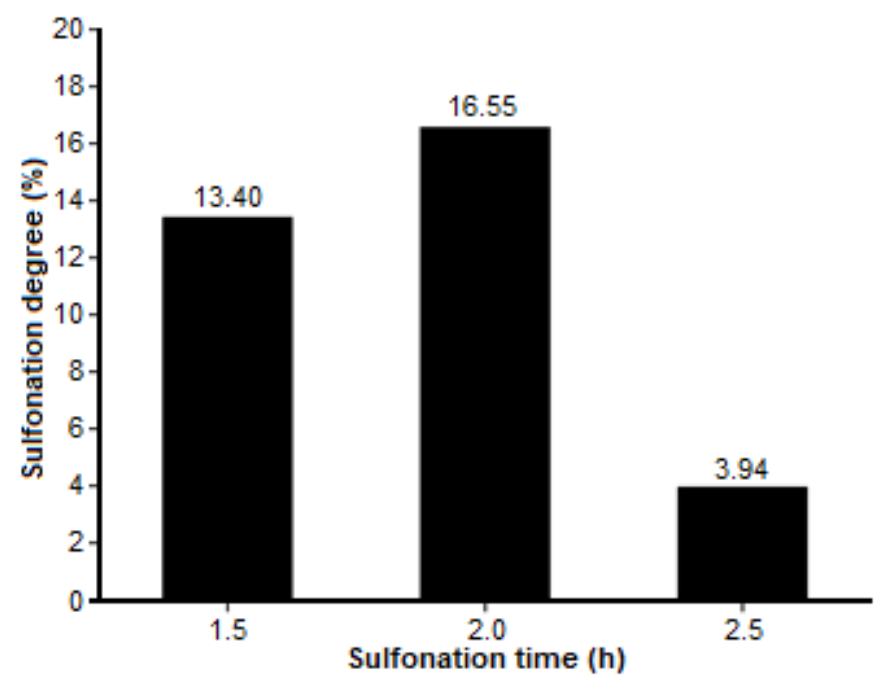

Fig 5. Sulfonation degree of sulfonated PEGDAF

of sulfonation value within $2 \mathrm{~h}$ is illustrated in Fig. 5 . However, an additional $30 \mathrm{~min}$ of sulfonation results in 
a decrease in the degree of sulfonation. This is probably due to the reversibility of the sulfonation process, in which the reaction runs until an optimized number of sulfonate groups is attached. The additional time makes de-attachment of the sulfonate group to obtain a lower sulfonation degree. In general, this reaction shows a typical trend of the sulfonation reaction where the rate at the initial stage goes fast and tends to slow down due to the influence of the steric hindrance, which increases because it is in the form of a polymer.

Another factor likely to affect the low sulfonation degree is the presence of water and acid in the sulfonation reaction, and this is capable of causing side reactions in PEGDAF in an ester group, which is easily hydrolyzed in the presence of sulfuric acid, as shown in Fig. 6. The longer the reaction time, the greater the chance of breaking the ester group's polymer chain, making the shorter polymer chain more soluble in water. Therefore, the sulfonation product obtained remains with a small degree of sulfonation, supported by the smaller reaction yield. The sulfonation interval time of $1.5,2.0$, and $2.5 \mathrm{~h}$ yielded 96 , 92 , and $71 \%$, respectively. It can be concluded that the optimum time for sulfonation of PEGDAF is $2 \mathrm{~h}$.

\section{Determination of Thermal Properties}

The thermal properties of PEGDAF and sulfonated PEGDAF were investigated by TGA and DTG techniques. Fig. 7 shows that the TGA and DTG curves obtained thermally stable copolymers, while the polymers exhibited two steps of degradation patterns

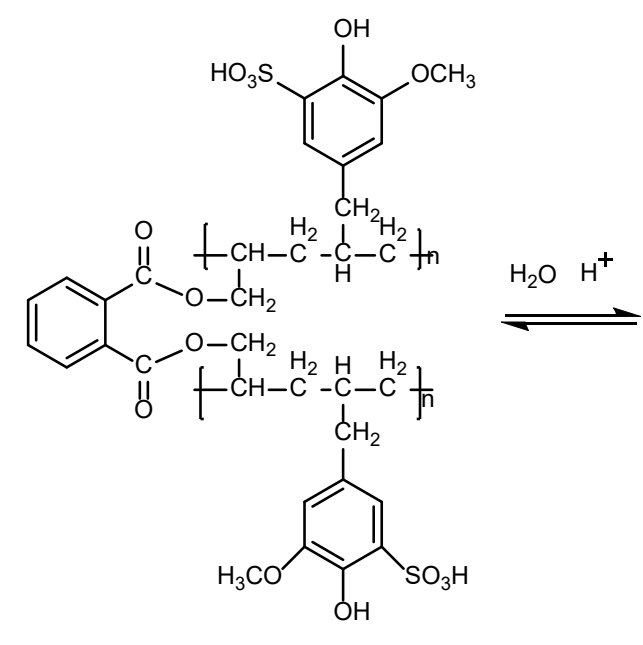

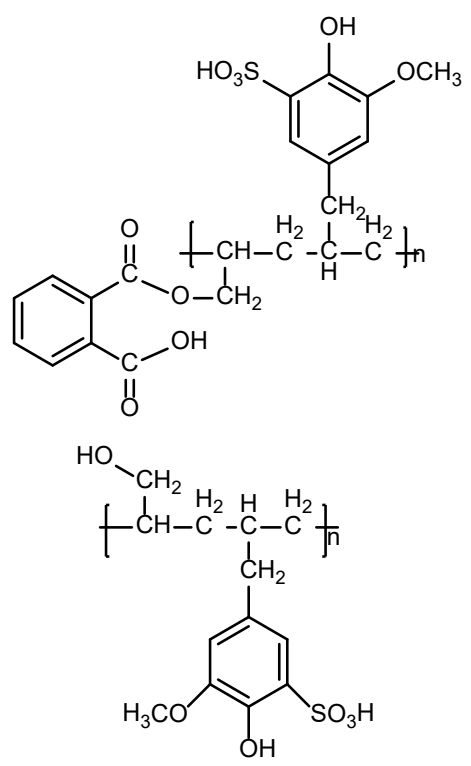

Fig 6. Hydrolysis of PEGDAF in the presence of water and acid
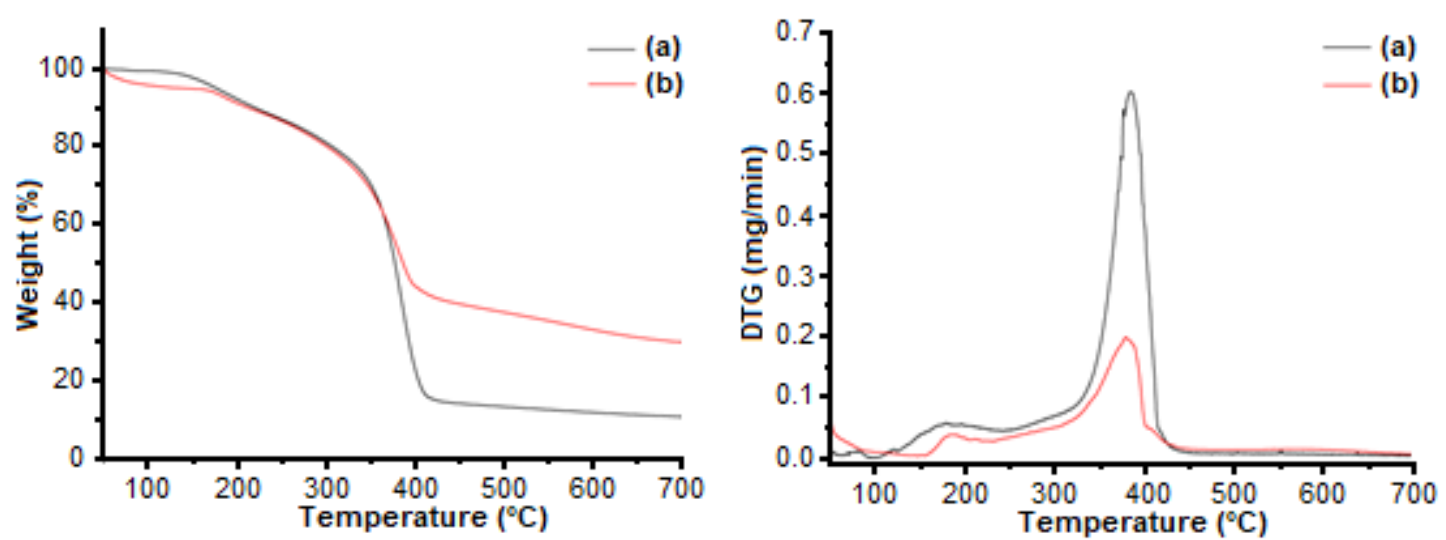

Fig 7. TGA (left) and DTG (right) graphs of (a) PEGDAF and (b) sulfonated PEGDAF 
under a nitrogen atmosphere. The initial degradation step was observed at room temperature of $200{ }^{\circ} \mathrm{C}$, which is attributed to the loss of water molecules absorbed. Subsequently, the loss of water molecule from sulfonated PEGDAF is higher due to more water is absorbed by the $\mathrm{SO}_{3} \mathrm{H}$ groups. The second main weight loss step that started above $350{ }^{\circ} \mathrm{C}$ was assigned to the polymer chain decomposition. The $10 \%$ weight loss temperatures of PEGDAF and sulfonated PEGDAF were 218 and $211^{\circ} \mathrm{C}$, respectively. In addition, the thermal stability of the polymer is slightly decreased with the sulfonation due to the degradation of sulfonic acid groups.

\section{Determination of Cation Exchange Capacity (CEC)}

The cation exchange capacity is an important parameter of the electrolyte polymer membrane in a fuel cell. This means that the material used as an electrolyte polymer membrane in a fuel cell needs to have an excellent ability to exchange cations [14]. This analysis aims to determine the ability of polymers to exchange cations that are bound to their functional groups with those given in the system. In this case, the cation bound to the functional group is the $\mathrm{H}^{+}$ion, while the cation in the system is the $\mathrm{Na}^{+}$ion. The graph representing the effect of sulfonation time on the value of cation exchange capacity is shown in Fig. 8.

Fig. 8 shows that the cation exchange capacity value is directly proportional to the degree of sulfonation, which

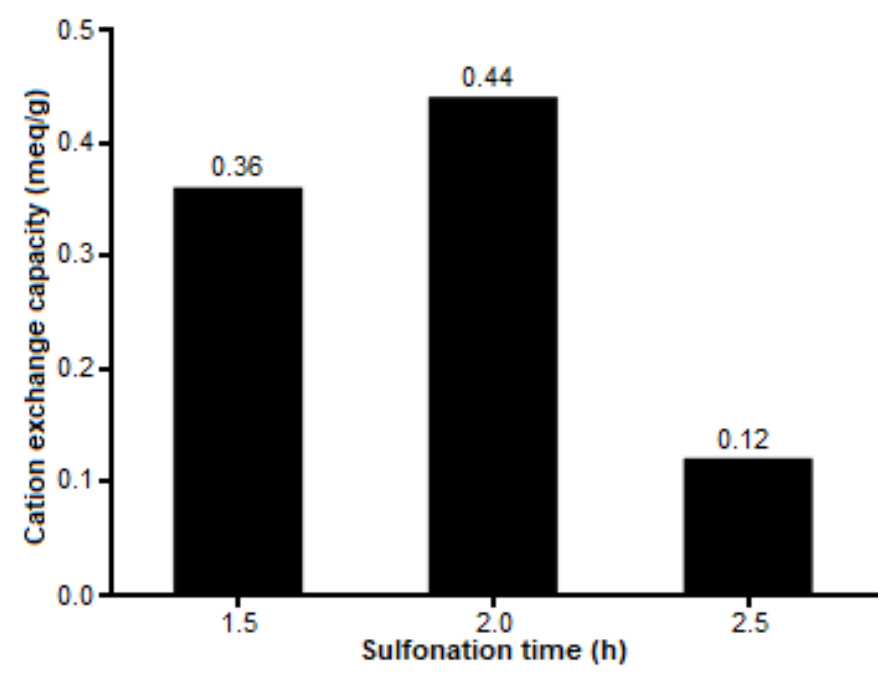

Fig 8. Relationship of sulfonation time to CEC of sulfonated PEGDAF provides advantages due to its strong acid property. Therefore, it increases the value of CEC with a rise in sulfonation time. Furthermore, the longer the sulfonation time, the more sulfonate $\left(-\mathrm{SO}_{3} \mathrm{H}\right)$ the groups substituted in the benzene ring, thereby leading to significant and more $\mathrm{H}^{+}$ions that can be exchanged. The easier a polymer to release $\mathrm{H}^{+}$ions, the greater the tendency to increase its cation exchange capacity. In its application as an electrolyte polymer membrane in a fuel cell, the polymer needs to have a large cation exchange capacity. This is because an increase in the value of cation exchange capacity leads to a rise in the ionic capacity, therefore increasing the polymer's ability to conduct electricity.

The cation exchange capacity analysis graph shows that the largest CEC value is the sulfonate PEGDAF with $2 \mathrm{~h}$ sulfonation time, i.e., $0.44 \mathrm{meq} / \mathrm{g}$. The CEC value decreased after $2 \mathrm{~h}$ because the sulfonate group was detached from the benzene ring and the optimum time for copolymer sulfonation (EG-DAF) is $2 \mathrm{~h}$.

\section{Determination of Proton Conductivity}

Proton conductivity is a polymer's ability to deliver protons and become an essential parameter of an electrolyte membrane. The determination of the proton conductivity value of sulfonated PEGDAF is presented in Fig. 9. The result showed that proton conductivity increased with a rise in the degrees of sulfonation. For proton exchange membranes, the number of sulfonate groups $\left(-\mathrm{SO}_{3} \mathrm{H}\right)$ found in sulfonated copolymers had a significant effect on the proton conductivity value. Substituted sulfonate groups increase hydrophilicity and then it can absorb more water molecules through hydrogen bonds. The water molecule will facilitate proton exchange; therefore, sulfonation has the ability to increase the proton conductivity of the polymer. Before sulfonation (PEGDAF), the polymer has a very small proton conductivity value, which is $0.031 \times 10^{-6} \Omega^{-1} \mathrm{~cm}^{-1}$. After sulfonation, the proton conductivity value was increased and the $2 \mathrm{~h}$ sulfonated PEGDAF owns the highest conductivity value of $8.343 \times 10^{-6} \Omega^{-1} \mathrm{~cm}^{-1}$. Based on the proton conductivity value, the sulfonated PEGDAF is categorized as a semiconductor material because its conductivity value is in the range of $10^{-8}-10^{3} \Omega^{-1} \mathrm{~cm}^{-1}$.

Ngadiwiyana et al. 


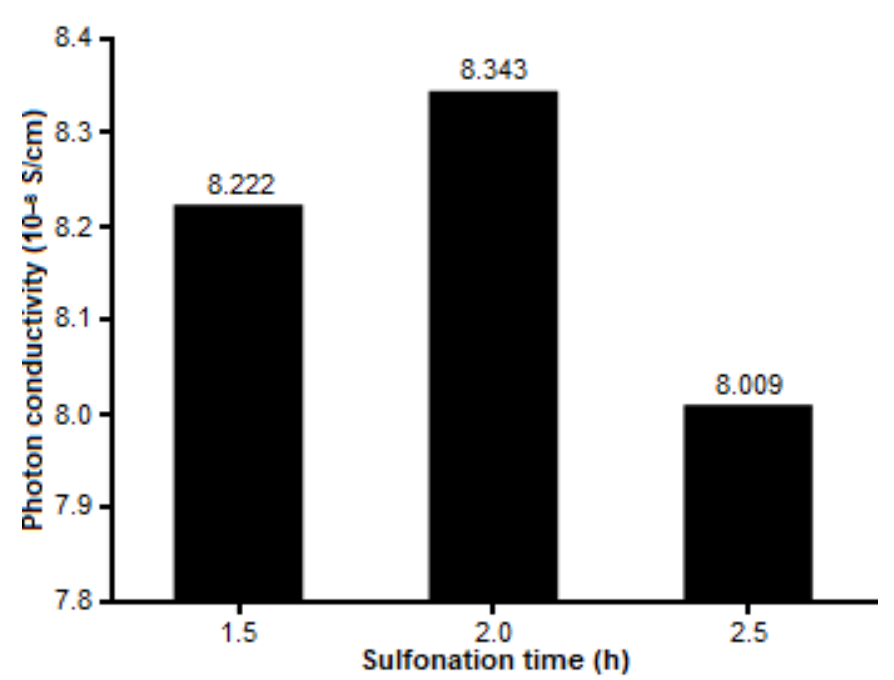

Fig 9. Proton conductivity value of PEGDAF sulfonate

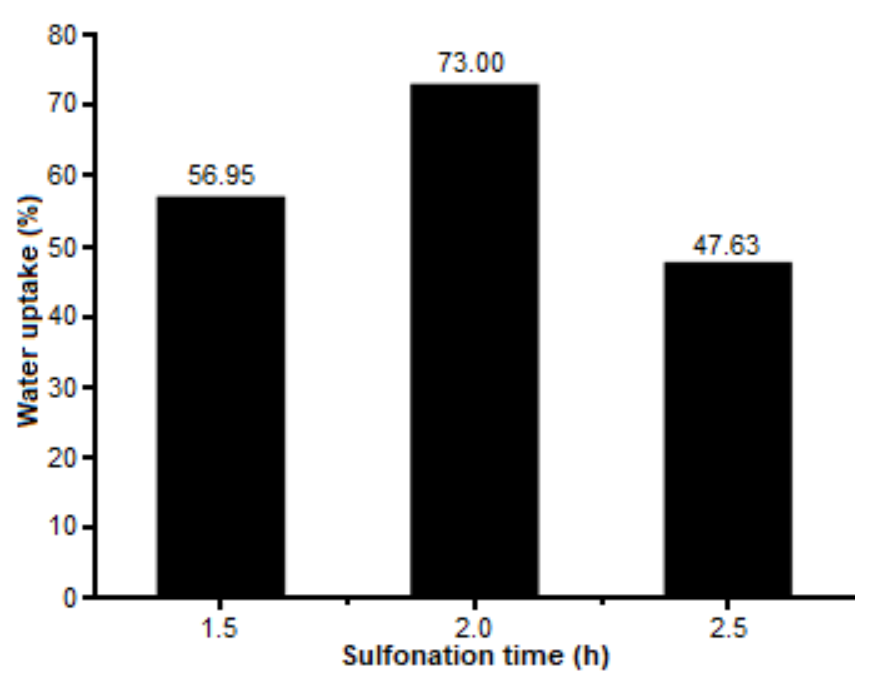

Fig 10. Water uptake value of PEGDAF sulfonated

Table 4. Comparison of the polymer properties with previous work by Muller et al. [7]

\begin{tabular}{lcccc}
\hline Sample & Sulfonation degree (\%) & CEC (meq/g) & Proton conductivity $\left(\right.$ S.cm $\left.{ }^{-1}\right)$ & Water uptake (\%) \\
\hline This work & 16.55 & 0.44 & $8.343 \times 10^{-6}$ & 73.0 \\
Muiller et al. [7] & $9-13$ & $0.3-1.24$ & $4.2 \times 10^{-10}-1.5 \times 10^{-7}$ & $8-36$ \\
\hline
\end{tabular}

\section{Determination of Water Uptake}

The ability of a polymer to absorb water is an important parameter in its application as an electrolyte membrane; this is because the water absorbed by the polymer facilitates proton transfer. The result of water uptake determination on sulfonated PEGDAF is shown in Fig. 10. The sulfonated PEGDAF in $2 \mathrm{~h}$ reaction time gives the highest value of water uptake (73\%), and this value decreased for the $2.5 \mathrm{~h}$ of sulfonated PEGDAF. A high degree of sulfonation shows that the higher the number of $-\mathrm{SO}_{3} \mathrm{H}$ groups in the copolymer, the higher the copolymer ability to absorb water. Nonetheless, very high water absorption induces membrane swelling, thereby reducing mechanical stability in the membrane (brittle).

Table 4 summarizes this work with the research carried out by Muiller et al. [7] on polymer properties. The sulfonation degree has a higher value and impact on the CEC and water uptake values. Consequently, it tends to improve the proton conductivity value with the eugenol based biopolymer used as a renewable source. This result shows that sulfonated PEGDAF is promising as a proton exchange membrane compared to the sulfonated and SEBS polymers reported by Muller.

\section{- CONCLUSION}

The copolymerization of eugenol-diallyl phthalate produces a solid brown copolymer with a melting point, molecular weight, and yield of $84^{\circ} \mathrm{C}, 6,329$ Daltons, and 85.96\%. In addition, the sulfonation of PEGDAF produces a black solid with a melting point of $133^{\circ} \mathrm{C}$ and the greatest degree of sulfonation is $16.55 \%$, at an optimum reaction time of $2 \mathrm{~h}$. The highest proton conductivity, cation exchange capacity (CEC), and water uptake during $2 \mathrm{~h}$ of sulfonation were $8.343 \times 10^{-6} \mathrm{~S} \mathrm{~cm}^{-1}, 0.44 \mathrm{meq} / \mathrm{g}$, and $73.0 \%$, respectively.

\section{- ACKNOWLEDGMENTS}

The authors are grateful to the Directorate of Research and Community Service of the Ministry of Research and Technology and Higher Education of Indonesia for funding the 2019 PDUPT research grant with contract number 257-58/UN7.P4.3/PP/2019.

\section{- REFERENCES}

[1] Modjinou, T., Versace, D.L., Abbad-Andallousi, S., Bousserrhine, N., Dubot, P., Langlois, V., and Renard, E., 2016, Antibacterial and antioxidant 
bio-based networks derived from eugenol using photo-activated thiol-ene reaction, React. Funct. Polym., 101, 47-53.

[2] Eissen, M., Metzger, J.O., Schmidt, E., and Schneidewind, U., 2002, 10 Years after Rio-Concepts on the contribution of chemistry to a sustainable development, Angew. Chem. Int. Ed., 41 (3), 414436.

[3] Khalil, A.A., Ur Rahman, U., Khan, R.M., Sahar, A., Mehmood, T., and Khan, M., 2017, Essential oil eugenol: Sources, extraction techniques and nutraceutical perspectives, RSC $A d v$., 7, 3266932681.

[4] Neda, M., Okinaga, K., and Shibata, M., 2014, Highperformance bio-based thermosetting resins based on bismaleimide and allyl-etherified eugenol derivatives, Mater. Chem. Phys., 148 (1-2), 319-327.

[5] Li, Q., Ma, Z., Yue, Q., Gao, B., Li, W., and Xu, X., 2012, Synthesis, characterization and swelling behavior of superabsorbent wheat straw graft copolymers, Bioresour. Technol., 118, 204-209.

[6] Munavalli, B.B., and Kariduraganavar, Y.M., 2018, Enhancement of fuel cell performance of sulfonated poly(arylene ether ketone) membrane using different crosslinkers, J. Membr. Sci., 566, 383-395.

[7] Müller, F., Ferreira, C.A., Franco, L., Puiggalí, J., Alemán, C., and Armelin, E., 2012, New sulfonated polystyrene and styrene-ethylene/butylene-styrene block copolymers for applications in electrodialysis, J. Phys. Chem. B, 116 (38), 11767-11779.

[8] Ngadiwiyana, Ismiyarto, Gunawan, Purbowatiningrum, R.S., Prasetya, N.B.A., Kusworo, T.D., and Susanto, H., 2018, Sulfonated polystyrene and its characterization as a material of electrolyte polymer, J. Phys. Conf. Ser., 1025, 012133.

[9] Liu, S., Wang, L., Ding, Y., Liu, B., Han, X., and Song, Y., 2014, Novel sulfonated poly(ether ether ketone)/polyetherimide acid-base blend membranes for vanadium redox flow battery applications, Electrochim. Acta, 130, 90-96.

[10] Zhu, Y., Liang, C., Bo, Y., and Xu, S., 2015, Compatibilization of polypropylene/recycled polyethylene terephthalate blends with maleic anhydride grafted polypropylene in the presence of diallyl phthalate, J. Polym. Res., 22 (3), 35.

[11] Prasetya, N.B.A., Ngadiwiyana, Ismiyarto, and Purbowatiningrum, R.S., 2019, Synthesis of copolymer eugenol crosslinked with divinyl benzene and preliminary study on its antibacterial activity, IOP Conf. Ser.: Mater. Sci. Eng., 509, 012102.

[12] An, D., Wu, B., Zhang, G., Zhang, W., and Wang, Y., 2016, Gradiently crosslinked polymer electrolyte membranes in fuel cells, J. Power Sources, 301, 204209.

[13] Zhai, S., Dai, W., Lin, J., He, S., Zhang, B., and Chen, L., 2019, Enhanced proton conductivity in sulfonated poly(ether ether ketone) membranes by incorporating sodium dodecyl benzene sulfonate, Polymers, 11 (2), 203.

[14] Wang, Q., Lu, Y., and Li, N., 2016, Preparation, characterization and performance of sulfonated poly(styrene-ethylene/butylene-styrene) block copolymer membranes for water desalination by pervaporation, Desalination, 390, 33-46.

[15] Guimet, A., Chikh, L., Morin, A., and Fichet, O., 2016, Strengthening of perfluorosulfonic acid ionomer with sulfonated hydrocarbon polyelectrolyte for application in mediumtemperature fuel cell, J. Membr. Sci., 514, 358-365.

[16] Larminie, J., and Dicks, A., 2013, Fuel Cell Systems Explained, $2^{\text {nd }}$ Ed., John Willey \& Son, Chichester, England.

[17] Fang, J.H., 2018, "Polyimide proton exchange membranes" in Advanced Polyimide Materials, Synthesis, Characterization and Applications, Eds. Yang, S.Y., Elsevier Science, Amsterdam, 323-383.

[18] Kiswandono, A.A., Hadi, S., Mudasir, Sinjia, F., Sari, M.Y., and Irfan, M., 2019, Copoly eugenol crosslinked dialylphthalate $8 \%$ as a carrier in phenol and $\mathrm{Pb}$ (II) metal transport, J. Phys. Conf. Ser., 1338, 012004.

[19] Parnian, M.J., Rowshanzamir, S., and Gashoul, F., 2017, Comprehensive investigation of physicochemical and electrochemical properties of sulfonated poly(ether ether ketone) membranes with different degrees of sulfonation for proton 
exchange membrane fuel cell applications, Energy, 125, 614-628.

[20] Tang, Y., Xue, Z., Zhou, X., Xie, X., and Tang, C.,
2014, Novel sulfonated polysulfone ion exchange membranes for ionic polymer-metal composite actuators, Sens. Actuators, B, 202, 1164-1174. 